THE RIGHT TO LOOK 


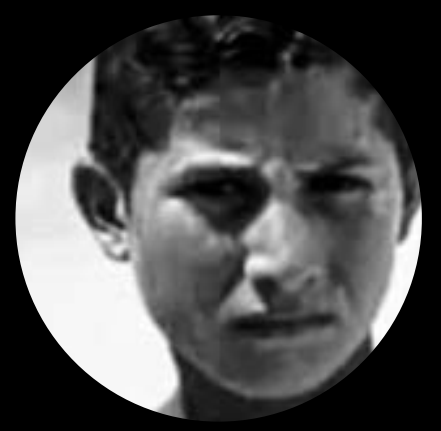

Duke University Press Durham \& London 2011 


\section{THE RIGHT TO LOOK}

A COUNTERHISTORY OF VISUALITY

Nicholas Mirzoeff 
(C) 2011 Duke University Press

All rights reserved

Printed in the United States of America on acid-free paper @

Designed by Amy Ruth Buchanan

Typeset in Bembo by Tseng Information Systems, Inc.

Library of Congress Cataloging-in-Publication Data appear on the last printed page of this book. 
For KRIS, KARIN, and KATHLEEN

with great love and respect, and in solidarity.

And for HANNAH in hope of better futures 
